\title{
Support networks and people with physical disabilities: social inclusion and access to health services
}

Cristina Marques de Almeida Holanda ${ }^{1}$

Fabienne Louise Juvêncio Paes de Andrade ${ }^{2}$

Maria Aparecida Bezerra ${ }^{2}$

João Paulo da Silva Nascimento ${ }^{2}$

Robson da Fonseca Neves ${ }^{2}$

Simone Bezerra Alves ${ }^{2}$

Kátia Suely Queiroz Silva Ribeiro ${ }^{2}$

\footnotetext{
${ }^{1}$ Área Técnica de Saúde da Pessoa com Deficiência da Secretaria Estadual de Saúde da Paraíba.Av. Dom Pedro II 1826, Torre. 58040-903 João Pessoa PB Brasil.

cristinamahd@gmail.com

${ }^{2}$ Departamento de

Fisioterapia da Universidade Federal da Paraíba.
}

\begin{abstract}
This study seeks to identify the formation of social support networks of people with physical disabilities, and how these networks can help facilitate access to health services and promote social inclusion. It is a cross-sectional study, with data collected via a form applied to physically disabled persons over eighteen years of age registered with the Family Health Teams of the municipal district of João Pessoa in the state of Paraiba. It was observed that the support networks of these individuals predominantly consist of family members (parents, siblings, children, spouses) and people outside the family (friends and neighbors). However, $50 \%$ of the interviewees declared that they could not count on any support from outside the family. It was observed that the support network contributes to access to the services and participation in social groups. However, reduced social inclusion was detected, due to locomotion difficulties, this being the main barrier to social interaction. Among those individuals who began to interact in society, the part played by social support was fundamental.
\end{abstract}

Key words Social support, Disabled persons, Access to health services, Socialization 


\section{Introduction}

The World Health Organization (WHO) says that $10 \%$ of the world's population has some type of disability ${ }^{1}$. Data from the demographic Census 2010 shows that in Brazil more than 45 million residents have some type of disability. It is estimated that more than 13 million people have some form of motor disability, representing a significant share of the population that requires governmental or civil society support to ensure their social inclusion ${ }^{2}$.

In the search for an "inclusive society", the United Nation's General Assembly agreed, through Resolution 45/91, the objective that by the year 2010 we would have a more inclusive society for all $^{3}$, yet in reality we are far from this goal being met. People with disabilities still face social, economic and cultural difficulties in relation to social inclusion. Coupled with the above they also experience mobility difficulties on the streets and accessibility problems when in buildings.

In Brazil, people with disabilities, have their social rights upheld by the Federal Constitution ${ }^{4}$, in order to protect their social life and in their right to work, by means of a set of judicial measures that can lead to the obtaining of compensation ${ }^{5}$.

Among the rights that are constitutionally guaranteed, is the right to health, which is of particular importance. In accordance with the principle of universal access to the Brazilian National Health Service (known by the acronym SUS), every Brazilian citizen should have access to health services, without exceptions. The document establishing the National Health Policy for Persons with Disabilities, approved in 2008 by the Ministry of Health, establishes guidelines and institutional responsibilities, with a view to creating conditions for the restitution of the rights for the disabled. The policy defines the role of each government department, so as to ensure that health care, public assistance, protection and security of those with disabilities forms an integral part of Government policy ${ }^{6}$.

However, it was observed that the health care of people with disabilities is still very much restricted to rehabilitation centers and other related services, which can compromise their access to services. This is particularly the case where one considers the untapped potential of these local health service providers who, at the moment, cannot guarantee tailored services for the disabled. Furthermore, little is known about how the services are organized, in relation to the architectural design of the health centers and what qualifications are needed by contracted health care professionals, to meet the needs of people with disabilities?

The issue of access to health services may be even more problematic for people with motor disabilities, whose limitations require there to be adequate means of transportation in order to travel. There are times when even though a particular service has been guaranteed to a disabled person, the person often doesn't have the financial or physical means to get to the place where the service is being provided. This subsequently results in a missed opportunity to receive health care which in itself can make the person's situation worse ${ }^{8}$.

Due to the difficulty of travel and access to rehabilitation services, people with disabilities have a restricted social life that revolves around their family, with little opportunity for social inclusion. This, in turn, creates the condition known as social isolation?.

Therefore, depending on the type of support given and the levels of participation from others, the disabled person can overcome the aforementioned limitations. This support, customarily, comes from family members, neighbors and friends, as well as, health professionals who all are, in one way or another, involved in helping them. The formation of a social support networks, is of fundamental importance in the life and quality of care persons with disabilities.

Social support, therefore, is defined as any information, spoken or not, and/or material assistance, offered by groups and/or people who know each other, that result in emotional outcomes and/or positive behavior ${ }^{10}$. This support can be through access for individuals to practical services and material resources. It can also be given through affective expressions of love and affection. When we refer to such emotions, this means showing empathy, affection, love, confidence, esteem, listening and showing interest in someone. Another form of support is through positive social interaction, which refers to people being available to interact with the disabled in a fun and relax manner ${ }^{11}$. Therefore the type of support that I have just outlined, if done in a certain social context, would constitute as being offered as part of a social support network.

There is evidence that suggests that the presence of a disease in a person, especially if chronic, can lower the quality of that persons social interactions and, in the long term, can reduce their possibility of accessing social networks ${ }^{11}$. This happens similarly with people who have disabilities. 
Considering the difficulties faced by people with disabilities and the importance of social support, it is necessary to identify the relevance of this support in relation to their social interaction. Therefore the objective of this study is to examine the constitutional makeup of identified social support networks for people with physical disabilities, and how these networks can contribute to facilitate access to health services and provide social inclusion.

\section{Methods}

This body of work involved field research which was both detailed and cross-sectional. This research was carried out between December 2007 and June 2008 by a Research Group from UFPB and the research was called Accessibility for People with Disabilities, with financial support that came from FAPESQ /CNPq/MS.

The sample for the study consisted of 120 volunteers, and was based on the population data for the city of João Pessoa as well as an estimate of the amount of people with physical disabilities in the world. The calculation for the size of the sample adheres to the following criteria: a $99 \%$ level of confidence rating; a margin of error of $3.3 \%$, knowledge of the percentage of the inhabitants in the city of João Pessoa that are over 18 years old, and finally the estimated percentage of persons with a physical disability ${ }^{2}$.

The study included people with physical disabilities having an impairment of the musculoskeletal system and mobility disabilities, who were older than 18 years old and were living in the city of João Pessoa. Those that were excluded from the research included people with disabilities that fell outside of the aforementioned because the disability was temporary in nature. Also excluded were either disabled people or their carers who were not able to respond to the survey.

In order to gain access to and select a sample we used people that were registered as physically disabled at the Family Health Team Centers (FHS) and screening was done based on the divisions of the Health District. These centers are operational units, setup on the basis of geographical area, epidemiology and political constituencies, that allows for the regionalization of health management by pooling health care equipment to be used as and when required for all in a given area ${ }^{12}$.

The criteria underpinning the choice of which Family Health Care Unit (USF) to use that would represent a given Health District was multiple and random, however the sample selection from the USF was done with more analytical thought. After this random selection of the USFs that represented each of the Districts was done, it was necessary to screen those that were registered as persons with physical disabilities.

Data was collected regarding the sociodemographic profile of the area, the social support networks, access to health services, and information relating to social interactions.

The people that were a part of the support networks were analyzed in four ways: personal relationships in families (which included the nuclear family and beyond); personal relationships with those considered to be like family; the types of support that was well established in both of the aforementioned types of relationships and how such support influenced their access to health services and their participation in social groups.

Having looked at both the immediate family support network and those that were considered as family members, it is important to emphasize that in addition to considering how often the disabled received support, we also observed the order of importance attributed to the family support network and the network of support made up of those considered to be family. Thus, the order of importance was measured through the designation of numbers in which the Arabic number " 1 " represented the highest degree of importance. This measurement was used for the two types of support networks as well as for evaluating how these support networks influenced social inclusion.

The reasons behind why someone had a particular physical disability were grouped according to the International Statistical Classification of Diseases and Related Health Problems - 10TH revision (ICD 10). It used the lists of categories with three characters ${ }^{13}$.

Initially a pilot study was conducted on the basis of which adjustments were to be made on the questionnaire. We used the coefficient alpha of Chronbach's alpha to test the reliability of the responses given using the questionnaire, which resulted in a coefficient of $0.67 ; 0.82$ and 0.73 for the socio demographic profile, access to health services and social support networks, respectively.

The participants included in the study agreed to participate in the study by signing a consent form. The research was conducted within the required standards stipulated in the Declaration of Helsinki and approved by the Research Ethics Committee for the Science of Health at the Federal University of Paraiba - CEP/CCS. 
The processing, storage and analysis of the data was done using the statistical program SPSS (Statistical Package for the Social Sciences), version 16.0. The statistical analysis was detailed, with the use of absolute and relative frequencies.

\section{Results}

The information obtained after the analysis of the data was grouped into three areas: sample profile (i.e. the social support networks), access to health services, and aspects related to social interaction.

\section{Socio demographic Profile}

As part of the research, 120 people were surveyed: $55 \%$ were female, $48.3 \%$ considered themselves to be white, $37.5 \%$ were either married or had a partner and $32.5 \%$ were literate despite not having completed primary school. This highlighted the high rate of illiteracy which we noted covered $30.8 \%$ of the sample surveyed (Table 1 ).

Physical disabilities were categorized as congenital or occurring during someone's life after birth, according to the time of its discovery. Some were considered as congenital diseases, others were discovered during the embryonic period, while other disabilities occurred during delivery or soon after a birth. Thus, these disabilities were considered life long disabilities.

According to Table 1, the most prevalent disabilities were the ones that had come about during a person's life which amounted to $81.66 \%$ of the cases. We also used three age categories: young adult, adult and the elderly. This last category accounted for the highest number of participants $(46.7 \%)$.

The majority of the participants did not have private health insurance $(83.3 \%)$, nor did they have paid employment. They were ever confined to staying in their house or just outside their house (96.7\%). The number of people that didn't have paid employment was the same number of those considered disabled and who were in receipt of Social Security benefits (88.3\%). Amongst the benefits that were received, invalidity retirement benefit was received by $44.2 \%$ of the participants, followed by retirement benefit based on the amount of years worked (20\%) and state pensions $(14.2 \%)$. The other benefits were received by $10 \%$ of our participants. We took into account people's personal income of which $59.2 \%$ received the equivalent to a minimum
Table 1. The Sociodemographic make up of those with disabilities in João Pessoa, Paraíba, 2008.

\begin{tabular}{|c|c|c|}
\hline Variables & $\mathbf{n}$ & $\%$ \\
\hline $\begin{array}{l}\text { Sex } \\
\quad \text { Female } \\
\quad \text { Male }\end{array}$ & $\begin{array}{l}66 \\
54\end{array}$ & $\begin{array}{l}55.0 \\
45.0\end{array}$ \\
\hline $\begin{array}{l}\text { Ethnicity } \\
\text { White } \\
\text { Mixed Race } \\
\text { Black } \\
\text { Mixed Race } \\
\text { Not reported }\end{array}$ & $\begin{array}{r}58 \\
40 \\
13 \\
7 \\
2\end{array}$ & $\begin{array}{r}48.3 \\
33.3 \\
10.8 \\
5.8 \\
1.7\end{array}$ \\
\hline $\begin{array}{l}\text { Marital Status } \\
\text { Married } \\
\text { Single } \\
\text { Widower } \\
\text { Divorced }\end{array}$ & $\begin{array}{l}45 \\
37 \\
28 \\
10\end{array}$ & $\begin{array}{r}37.5 \\
30.8 \\
23.3 \\
8.3\end{array}$ \\
\hline $\begin{array}{l}\text { Education } \\
\text { Illiterate } \\
\text { Literate } \\
\text { Primary School Completed } \\
\text { Secondary School Completed } \\
\text { University Education Completed } \\
\text { Not reported }\end{array}$ & $\begin{array}{r}37 \\
39 \\
24 \\
15 \\
4 \\
1\end{array}$ & $\begin{array}{r}30.8 \\
32.5 \\
20.0 \\
12.5 \\
3.3 \\
0.8\end{array}$ \\
\hline $\begin{array}{l}\text { When disability Occured } \\
\text { Congenital (at birth) } \\
\text { Occurred during life } \\
\text { Not reported }\end{array}$ & $\begin{array}{r}20 \\
98 \\
2\end{array}$ & $\begin{array}{r}16.7 \\
81.7 \\
1.8\end{array}$ \\
\hline $\begin{array}{l}\text { Age } \\
\qquad 18 \text { to } 40 \text { (young adult) } \\
41 \text { to } 60 \text { (adult) } \\
61 \text { to } 100 \text { (elderly) }\end{array}$ & $\begin{array}{l}25 \\
37 \\
58\end{array}$ & $\begin{array}{l}20.8 \\
30.8 \\
48.3\end{array}$ \\
\hline
\end{tabular}

wage, and we noted that some family incomes were increased through the periodic receipt of 2 to 5 salaries $(36.7 \%)$. Most of the participants $(44.2 \%)$ resided with approximately 4 to 6 people in their household.

It was noted that the high number of people with physical disabilities caused by strokes corresponded to $36.6 \%$. Other causes were: major traumatic life incidents (12.5\%), amputation due to diabetes $(8.3 \%)$, cerebral palsy $(7.5 \%)$, poliomyelitis $(7.5 \%)$, spinal cord injury $(5.8 \%)$, other/ not specified $(21.7 \%)$. The majority of the interviewees considered themselves to be disabled $(87.5 \%)$.

\section{Social support networks and access to health services}

According to Figure 1, the family categories most prevalent and most important were those 
that belonged to the nuclear family, that is, parents $(24.2 \%)$, children $(56.7 \%)$, husbands/wives (33.3\%) and siblings (22.5\%).

When looking at the degree of importance placed on family support, the support from parents was considered most important. The relationship with children showed the highest prevalence rate being the case for $56.7 \%$ of participants. Relationships with siblings, despite existing in a high number of cases, was considered low in relation to importance when looking at support networks.

Married people received the majority of their support from their husbands/wives and children, while single people received the most amount of support from parents and siblings. Widowers received support predominantly from their children. This study also noted that a high number of the participants with congenital disabilities were single.

In relation to those considered to be like family members (Figure 2) that provided a network of support, they were comprised of mainly friends or neighbors. There wasn't much difference in relation to the degree of importance given to both of the above despite not having the same high numbers of importance as other categories. Mention was also made of the support received from health professionals and religious people within the context of support networks. Support from co-workers wasn't often mentioned because few of our sample engaged in work activity. It is also worth noting that $50 \%$ our sample who had a physical disability didn't receive any support from anyone outside the family.

Amongst the types of support developed due to relationships, support from the family or from those considered to be like family provided material $(55.5 \%)$ or emotional $(84 \%)$ support. This last type of support was most prevalent and was considered the most important.

A large proportion of our sample $(89.2 \%)$ stated that the support they received helped with them gaining access to health services. In relation to gaining access to health services, $57.5 \%$ noted the importance of this support in order to make appointments and $67 \%$ in being accompanied to the doctors. No significant differences were noted in relation to the degree of importance attributed to the aforementioned.

\section{Aspects related to social interaction}

A significant number of participants in the sample $(71.7 \%)$ say they have difficulty in participating in local events, festivals or community meetings, mainly due to their own difficulties in physical movement $(72.1 \%)$, followed by a lack of adequate disabled-friendly streets and avenues (15.1\%). We noted that of the $21 \%$ of people who stated that they were able to participate in the above events without major problems, 50\%

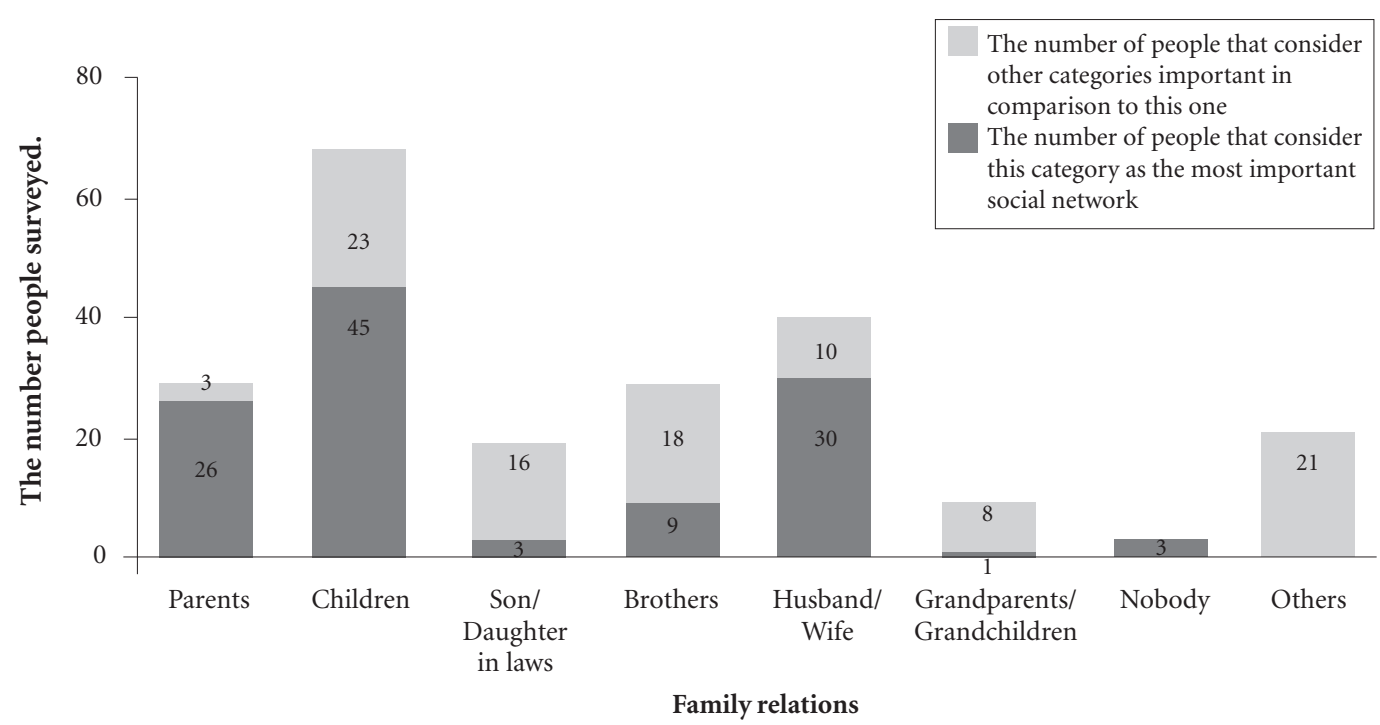

Figure 1. The make-up of the family support network and its order of importance. João Pessoa, Paraíba, 2008. 


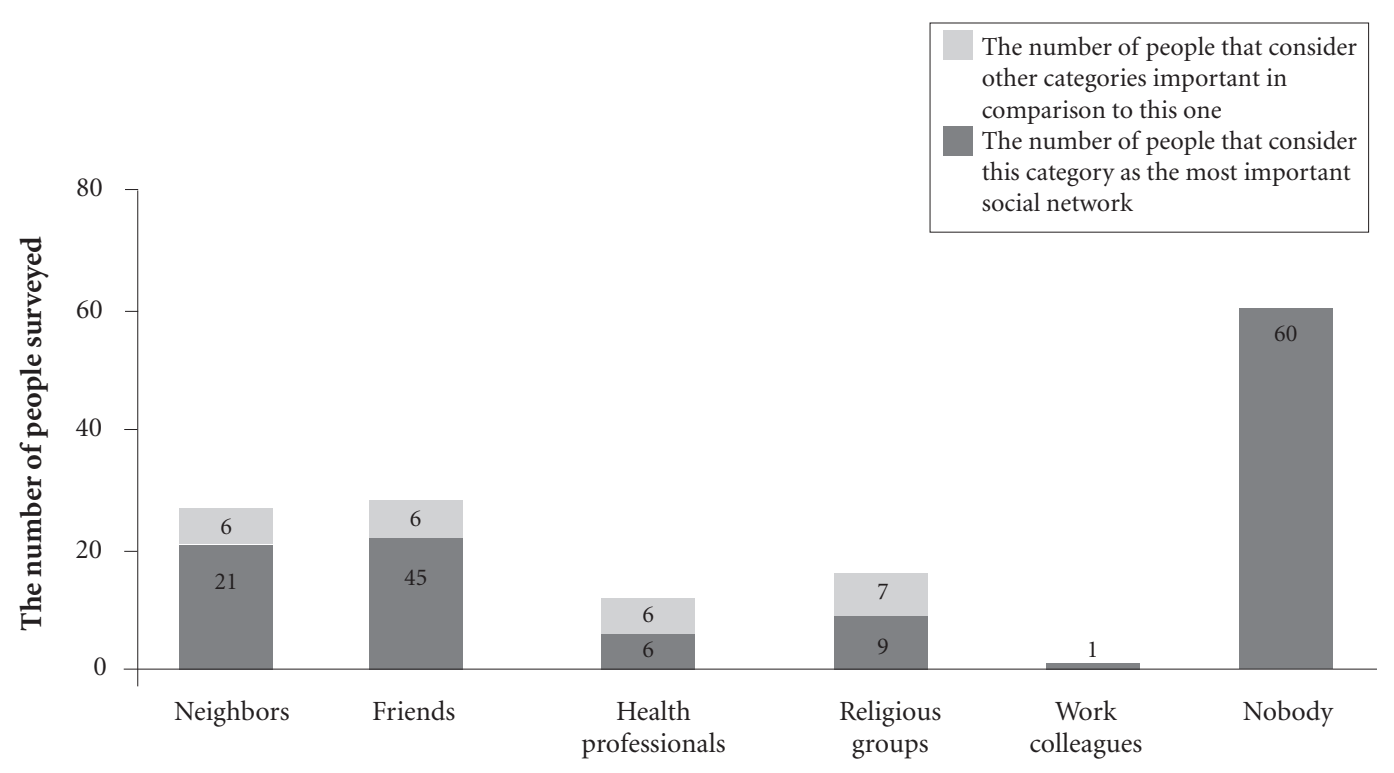

People outside of the family unit

Figure 2. The make-up of the social networks outside of the family unit and their order of importance. João Pessoa, Paraíba, 2008.

of them stated that companies helped in this respect. Also $16.7 \%$ stated that a major help was the proximity of the event to their place of abode.

Only $20.3 \%$ of our sample participated in any social group. Also amongst this group, 96\% of our sample highlighted their participation in a religious group. The main types of support received by these groups were spiritual support (91.7\%) and care/emotional support (41.7\%).

Amongst those who do not participate in groups, $37.5 \%$ demonstrated a desire to participate in one, citing that the main obstacle preventing them from doing so was due to physical mobility problems.

We noted that $23.3 \%$ of our sample had stopped being a part of a social group that they use to be a part of. Amongst the reasons given, again, difficulties in physical mobility was highlighted (78\%).

\section{Discussion}

The sociodemographic profile of the sample that was studied showed a relatively high amount of illiterate people (30.8\%). This number is higher than the figure presented by IBGE in 2009, which estimated that an average of $10 \%$ of Brazilians older than 15 years old are illiterate ${ }^{14}$.
The high rate of illiteracy in the population studied, together with the prevailing low personal income in this group (almost $60 \%$ of the subjects had an income equivalent to one monthly minimum wage) are factors that can negatively influence the social integration of these individuals, while at the same time they are indicators of a need for actions to be taken aimed at overcoming the difficulties imposed by socio-economic conditions.

The World Report on Disability ${ }^{15}$ has shown, based on the World Health Survey carried out between 2002-2004 (which looked at a total of 70 countries) that those who fell into the group of being either a woman, or living in near extreme poverty or were elderly were more likely to be disabled. This is particularly the case in developing countries.

The number of people that were disabled due to strokes, was high. The study carried out by the World Report on Disability ${ }^{15}$ has shown that increases in cases of diabetes, cardiovascular diseases (heart disease and stroke), mental disorders, cancer and respiratory diseases will have a profound effect on disabilities throughout the world.

Having a stroke is one of the main factors associated with causing disabilities in adults. This also proved to be the case in the sample of people that we studied especially amongst the elderly. 
The rapid changes in the demographics of our society have seen the increase in the amount of adults and elderly people. This fact coupled with modern lifestyles has increased the number of people with chronic non-transmissible diseases ${ }^{17}$. This rising trend is creating serious public health concerns which demand urgent action and continuous monitoring.

People with physical disabilities in this study had their social support network strongly related to their nuclear family. There are few studies that look at the social support networks of a particular public. Aoki et al. ${ }^{18}$ conducted a study that involved 57 people with various types of disabilities, amongst children, adults and the elderly, and it was found that their social support network centered around their nuclear family, with little support from extended family members, friends, neighbors and social facilities.

Bittencourt et al. ${ }^{19}$ studied, using qualitative methods, the social networks used by families of those that are deaf. The interviews, that formed part of the study, highlighted the interweaving of relations among family members, other relatives, friends, neighbors, professionals, private organizations and public services. When looking at the relationship between neighbors and the family of deaf people, this relationship appeared to be weak due to a lack neighborly spirit and trust. Also when looking at the support network that involved extended family members, it was noted that importance was placed on geographical proximity and the participation of the "grandmother" in supporting the disabled person. This latter finding did not tally with the results of our study which didn't show, in large numbers, this type of support network.

The study by Rosa et al..$^{20}$ on support networks with the elderly found that the amount of support received in relation to a person's marital status, tends to be lower for the unmarried, widowed and people that are divorced, when compared to married couples. Their results showed that children are fundamental in the support of elderly people, leaving the elderly who do not have children, at a disadvantage. Our study showed the importance of children in the make up of the family support network.

After characterizing the social networks of people with physical disabilities, (being either a part of the nuclear family or extended family) and having looked at the main types of support that exists for accessing health care, one salient fact was noted. Even though people with disabilities were tremendously helped by the two aforementioned groups, they still encountered difficulties in the areas of social interactions with social groups. They had a delimited social network restricted to a high percentage of them only receiving support from family members.

According to Ribeiro ${ }^{21}$, the network of people with physical disabilities, as well as those who have chronic diseases and disabling conditions, worsens over time. In these types of situations the work of the support network rests with the family which can prove to be an overwhelming burden for it. As a result of this, the disabled person becomes increasingly more isolated. We found that the disabled people that usually become isolated first, are those that become disabled during their lives and normally they become removed from their work or study.

Zołnierczyk-Zreda and Majewski ${ }^{22}$ highlight the difficulties in employing disabled people. They highlighted the problems in relation to labor productivity and the need to make adaptions to the work environment which can be costly. However, they emphasize the importance of the work to prevent the social exclusion of people with disabilities.

The difficulties in relation to mobility is pointed out as the main reason for the low social participation of the disabled. This difficulty was evident in $15.1 \%$ of the cases that we looked at in relation to the accessibility to buildings for the disabled. These problems raised, due to inadequately designed buildings, were also highlighted by our Research Group. In particular, our Research Group noted an association between poorly designed buildings and the level of access to health services for the elderly in $244^{23}$ cases. Also $63.9 \%$ of the 523 people questioned, stated that a lack of sufficient resources was the reason for not being able to make these adjustments to the buildings ${ }^{24}$.

The access to public facilities (buildings and roads) is fundamental for the inclusion of people with disabilities in everyday activities in any society, as well as the availability of technologies which can enhance their lives. This, in particular, can be a powerful resource to increase independence and improve the participation of disabled people in society ${ }^{15}$.

The fact that almost $80 \%$ of people with disabilities in this study did not participate in any social group, coupled with the fact that $50 \%$ of them did not have any support outside the family, shows the degree of isolation that these people are subjected to.

It creates a vicious circle in which isolation exacerbates the limitations and the limitations 
exacerbate the disability. It is believed, therefore, that the widening of support networks greatly enhances the chances for the disabled to become involved in different social groups. We found that simply having other people around them facilitated their social participation.

The results of this study suggested that religious groups play an important role in helping disabled people participate in social groups. This finding tallies with the findings of another study about the living conditions of persons with disabilities ${ }^{18}$. According to Parker ${ }^{25}$ religion provides for the disabled a religious, cultural and social identity, in the form of community events which creates community bonding. Therefore religion may be a very important social network for the disabled and can help them overcome the sense of social isolation.

There is strong evidence that states that a social network of stable, sensitive, active and reliable people can do the following: can help with health care $^{26}$, can act as carers and help with difficulties, affects the relevance and timeliness of the use of health services, speeds up forms of rehabilitation, and increases the chances of living longer ${ }^{27}$.

La Valla ${ }^{28}$ says that social support represents an alternative to support given by some professionals who deal with the health problems on a collective basis. Social support networks have been looked upon by the health community as a means to promote and restore health and well-being ${ }^{29}$.

In this sense, the role of health professionals has become ever more important in the widening and empowering of social support networks for people with physical disabilities. They need to encourage the development of social skills, which can be done through the support that they can give.

The intervention made by professionals involved in social networks, working with other people, can (re)activate social ties and stimulate the formation of new networks. It is necessary, for all parties involved, to know their own personal networks, seek ways to establish new contacts, help in reducing the sense of isolation and help in the restoration or establishment of social bonds ${ }^{21}$. It is worth remembering that every network has a certain inertia and its effectiveness will depend on the amount of attention, care and maintenance that it receives from its members, i.e. it demands a certain amount energy expenditure $^{27}$. The Community Health Workers and the FHTs can help in this process.
It is suggested that there needs to be more input from health care bodies that specifically address social support networks that are focused on people with physical disabilities. This emphasis should also be placed on others that are apart of these networks including trying to encourage more female participation and giving more support to families in health care issues.

Therefore when weaknesses are identified in support networks for the disabled, actions need to be taken to improve the health care provided by these networks. Such actions may be coordinated principally by the ESF through strengthening and expanding networks of support for people with disabilities, in order to increase the availability of support from other sources. It is a strategy that can contribute towards greater social inclusion and can guarantee access to social rights, particularly the right to health.

This is a multifaceted approach, which contains different elements, which was one of the main difficulties with this study particular in comparing our results with other studies. Our knowledge about support networks for the disabled needs to be extended and we need more analytical studies that take into account experiential elements and the intersubjectivity of the area.

\section{Conclusion}

The personal support for people with physical disabilities in our sample was restricted to the population in the city of Joao Pessoa - Paraíba and it particularly revolved around a person's nuclear family. It was evident that the support network was important for accessing health services and for traveling.

We also found that difficulties lay in the disabled developing social relationships, forming new bonds through participating in extended family social groups, and mainly through traveling. These limitations have a direct impact on the level and nature of their participation in society.

At the same time we found that difficulties existed in the accessibility by the disabled to health care services and their ability to have more social interactions. We also noted the potential for social networks to help with finding solutions in primary care services if they are incorporated in the work given by health care professionals. Participation in and expansion of social support networks can help to remove the feeling of isolation and reduce the amount of worked placed on the family unit. 


\section{Collaborations}

CMA Holanda, FLJS Amaral, MAB Quirino, JPS Nascimento, RF Neves, SB Alves e KSQS Ribeiro participated equally in all stages of preparation of the article.

\section{Acknowledgements}

We are grateful to the Foundation for Support to Research of the State of Paraíba, FAPESQ, the Brazilian Ministry of Health and the National Council for the Development of Scientific and Technological Research, $\mathrm{CNPq}$, for their financial support.

\section{References}

1. Organização Mundial da Saúde (OMS). Disability and Rehabilitation WHO Action Plan 2006-2011. Geneva: OMS. [acessado 2013 Jul 15]. Disponível em: http:// www.who.int/disabilities/publications/dar_action_ plan_2006 to2011.pdf.

2. Instituto Brasileiro de Estatística e Geografia (IBGE). Censo demográfico 2010. Rio de Janeiro: IBGE; 2010. [acessado 2013 Jul 06]. Disponível em: http://www. ibge.gov.br.

3. Organização das Nações Unidas. Resolução n. ${ }^{\circ}$ 45/91 de 14 de dezembro de 1990. Trata da execução do Programa de Ação Mundial para as Pessoas Deficientes e da Década das Pessoas com Deficiência das Nações Unidas. Assembleia Geral das Nações Unidas 1990; 14 dez.

4. Brasil. Constituição da República Federativa do Brasil. Brasília: Senado Federal; 1998.

5. Chatt CB. A proteção constitucional das pessoas portadoras de deficiência e os aspectos jurídicos para sua efetivação [acessado 2011 maio 05]. Disponível em: http:// www.uj.com.br/publicacoes/doutrinas.

6. Brasil. Ministério da Saúde (MS). Política Nacional de Saúde da Pessoa Portadora de Deficiência. Brasília: MS; 2008.

7. Szwarcwald CL, Mendoça MHM, Andrade CLT. Indicadores de atenção básica em quatro municípios do Estado do Rio de Janeiro, 2005: resultados de inquérito domiciliar de base populacional. Cien Saude Colet 2006; 11(3):643-655.

8. Siqueira FCV, Facchini LA, Silveira DS, Piccini RX, Tomasi E. Barreiras arquitetônicas a idosos e portadores de deficiência física: um estudo epidemiológico da estrutura física das unidades básicas de saúde em sete estados do Brasil. Cien Saude Colet 2009; 14(1):39-44.

9. Griep RH, Chor D, Faerstein E, Werneck GL, Lopes CS. Validade de constructo de escala de apoio social do Medical Outcomes Study adaptada para o português no Estudo Pró-Saúde. Cad Saude Publica 2005; 21 (3):703714.

10. Due P, Holstein B, Lund R, Modvig J, Avlund K. Social relations: Network, support and relational strain. Soc Sci Med 1999; 48(5):661-673.

11. Minkler M. Building supportive ties and sense of community among the innercity elderly: the Tenderloin Outreach Project. Health Educ Q 1985; 12(4):303314.

12. Melo CF, Alchieri JC, Araújo Neto JL. Sistema Único de Saúde: uma avaliação realizada em Natal, Rio Grande do Norte, Brasil. Psico-USF 2012; 17(1):63-72.

13. Organização Mundial da Saúde (OMS). Classificação estatística internacional de doenças e problemas relacionados à saúde. $10^{\mathrm{a}}$ revisão. $7^{\mathrm{a}}$ ed. São Paulo: EDUSP; 2008.

14. Instituto Brasileiro de Estatística e Geografia (IBGE). Pesquisa Nacional por Amostra de Domicílios 2009. Rio de Janeiro: IBGE; 2009. [acessado 2010 out 20]. Disponível em: www.ibge.gov.br.

15. Organização Mundial da Saúde. Relatório mundial sobre a deficiência. São Paulo: SEDPcD; 2012.

16. Mendis S. Stroke disability and rehabilitation of stroke: World Health Organization perspective. Int J Stroke 2013; 8(1):3-4. 
17. Brasil. Ministério da Saúde (MS). Plano de ações estratégicas para o enfrentamento das doenças crônicas não transmissiveis (DCNT) no Brasil. Brasília: MS; 2011.

18. Aoki M, Oliver FC, Nicolau SM. Considerações acerca das condições de vida das pessoas com deficiência a partir de um levantamento em uma unidade básica de saúde de um bairro periférico do município de São Paulo. O Mundo da Saúde 2011; 35(2):169-178.

19. Bittencourt ZZLC, Françozo MFC, Monteiro CR, Francisco DD. Surdez, redes sociais e proteção social. Cien Saude Colet 2011; 16(Supl. 1):769-776.

20. Rosa TEC, Benício MHD, Alves MCGP, Lebrão ML. Aspectos estruturais e funcionais do apoio social de idosos do Município de São Paulo, Brasil. Cad Saude Publica 2007; 23(12):2982-2992.

21. Ribeiro KSQS. A Relevância das Redes de Apoio Social no Processo de Reabilitação. RBCS 2010; 13(2):69-78.

22. Zołnierczyk-Zreda D, Majewski T. Adaptation of the working environment to the capacities of workers with physical, intellectual and mental disabilities. Med $\mathrm{Pr}$ 2012; 63(4):493-504.

23. Amaral FLJS, Motta MHA, Silva LPG, Alves SB. Fatores associados com a dificuldade no acesso de idosos com deficiência aos serviços de saúde. Cien Saude Colet 2012; 17(11):2991-3001.

24. Amaral FLJS, Holanda CMA, Quirino MAB, Nascimento JPS, Neves RF, Ribeiro KSQS, Alves SB. Acessibilidade de pessoas com deficiência ou restrição permanente de mobilidade ao SUS. Cien Saude Colet 2012; 17(7):1833-1840.

25. Parker C. Religião popular e modernização capitalista: outra lógica na América Latina. Petrópolis: Vozes; 1996.

26. Escobar-Bravo MA, Puga González D, Martín-Baranera M. Protective effects of social networks on disability among older adults in Spain. Arch Gerontol Geriatr 2012; 54(1):109-116.

27. Sluzki C. A rede social na prática sistêmica: alternativas terapêuticas. São Paulo: Casa do Psicólogo; 1997.

28. Valla V. Redes Sociais, Poder e Saúde à Luz das Classes Populares numa Conjuntura de Crise. Interface (Botucatu) 2000; 4(7):37-56.

29. World Health Organization (WHO). The Ottawa charter for health promotion. Geneve: WHO; 1986.

Article submitted 06/10/2013

Approved 15/10/2013

Final version submitted 17/10/2013 